\title{
Urban Hydrology-Science Capabilities of the U.S. Geological Survey
}

Urbanization affects streamflow characteristics, coastal flooding, and groundwater recharge. Increasing impervious areas, streamflow diversions, and groundwater pumpage are some of the ways that the natural water cycle is affected by urbanization. Assessment of the relations among these factors and changes in land use helps water-resource managers with issues such as stormwater management and vulnerability to flood and drought. Scientists with the U.S. Geological Survey (USGS) have the expertise to monitor and model urban hydrologic systems. Streamflow and groundwater data are available in national databases, and analyses of these data, including identification of long-term streamflow trends and the efficacy of management practices, are published in USGS reports.

\section{Expertise and Resources}

The USGS scientists of the Northeast Region Urban Landscapes Capability Team share expertise and resources to provide and interpret data on a wide range of urban-related issues at local, regional, and national levels. These scientists use state-of-the-art monitoring, modeling, and laboratory methods to better understand hydrologic processes and their impacts on aquatic organisms and human life in urban environments. Examples of these efforts include operating continuous streamflow monitoring stations coupled with alert systems in flash-flood prone areas to provide the public with real-time warnings about flooding (http://waterwatch.usgs.gov/), generating data critical to refining inundation and storm surge forecasting models and maps, and providing emergency personnel with early warning of coastal flooding (http://water.usgs.gov/floods/ swath/). Assessing the interactions between surface water and groundwater using advanced monitoring technologies and modeling applications informs urban planners and stakeholders about water resources. See http://ny.water.usgs. gov/projects/SOTA/ and Provost and others (2009) for more details.

\section{Urban Streams}

The USGS currently operates a network of over 8,000 streamgages (http://waterdata.usgs.gov/nwis/rt) as part of its cooperative water program, which is used by local, state, and Federal cooperators; stakeholders; and other government agencies. Increases in stormwater runoff from impervious surfaces (roads, parking lots, and roofs) increase peak flows during rain events, which can degrade stream channel stability. Advanced monitoring equipment, such as noncontact radar-stage sensors and acoustic Doppler velocimeters, are used to understand rapidly-changing hydrodynamic conditions in streams and estuaries in real time (http://ny.cf.er.usgs.gov/nyprojectsearch/projects/LK00-FKD-0300. html). The USGS modeling program, Stochastic Empirical Loading and Dilution Model (also known as SELDM), was created in cooperation with the Federal Highway Administration to determine the risk of adverse effects of storm runoff, the potential need for mitigation measures, and the effectiveness of management measures for reducing these risks (https://pubs.er.usgs.gov/publication/tm4C3). Information about how stream and coastal flooding are affected by land use helps municipal officials manage their current and future vulnerability to floods. Scientists with the USGS also work with urban planners and community groups to study the effects of stream restoration such as daylighting (uncovering buried streams) and dam removal.

\section{Groundwater in Urban Areas}

The USGS operates an extensive network of groundwater wells that can be used to assess groundwater level and quality and aquifer properties. Urbanization can affect groundwater resources in many ways. Impervious surfaces in an

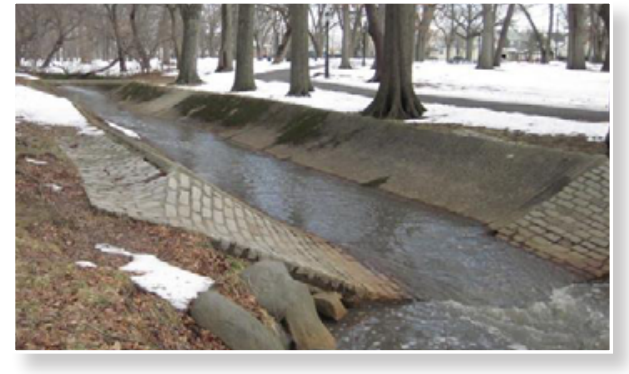

Cement-lined stream in Queens County, New York. Photograph from U.S. Geological Survey.

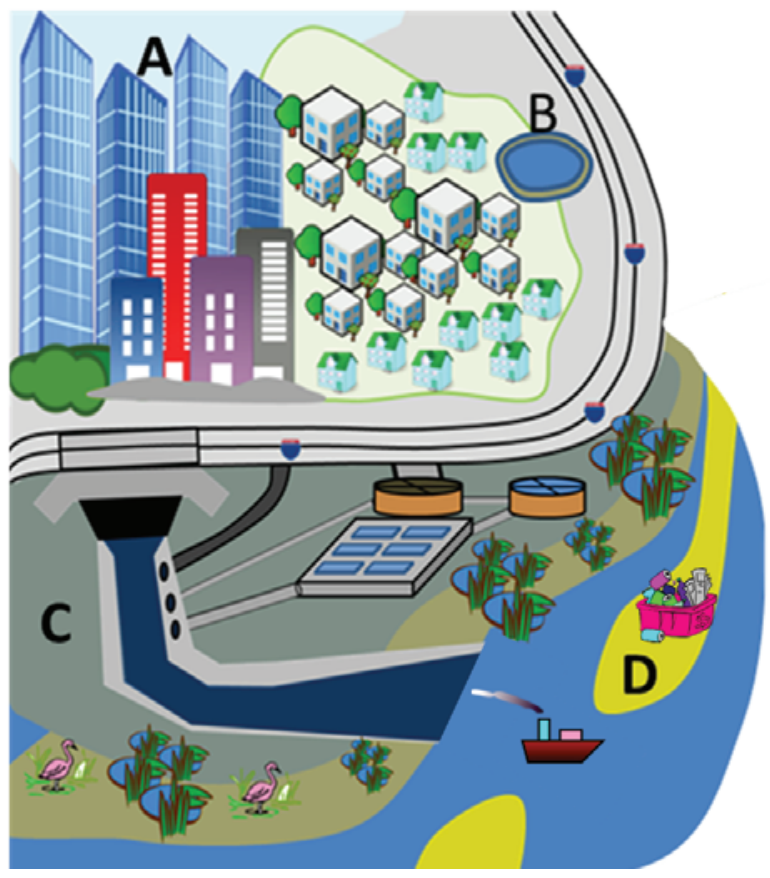

Urban hydrology qualifies and quantifies effects of $A$, impervious surfaces, $B$, groundwater sourcing, $C$, stream response time and sewage overflow, and $D$, waterway impairment. 
Conceptual model showing how a discharge hydrograph is altered by increases in impervious areas throughout a watershed. Water runs off faster from streets and roofs than from natural vegetated areas. The construction of parking lots, artificial channels, and storm sewers reduce the time required for a given amount of water to run off into neighboring streams. Effects of decreasing lag time are higher in-stream velocities, increased erosion, higher instantaneous discharge, and increased potential for flash flooding. Image modified from Leopold, 1968.

urban landscape alter groundwater recharge. Sanitary infrastructure alters the natural water budgets. Groundwater withdrawal for public supply removes water from storage and can decrease base flows to streams. Above-normal precipitation events, rising sea level, and climate change may exacerbate current infrastructure flooding issues by increasing groundwater levels. Conversely, droughts and supply withdrawals can lower groundwater levels and may lead to land subsidence or saltwater intrusion. To better understand complex aquifer systems and their potential response to changes in precipitation, urbanization, wastewater recharge, or withdrawal, the USGS has developed numerous groundwater flow models in urban areas using computer programs such as MODFLOW. Models such as these greatly improve the understanding of groundwater processes and groundwater response to stressors such as intensive supply pumping.

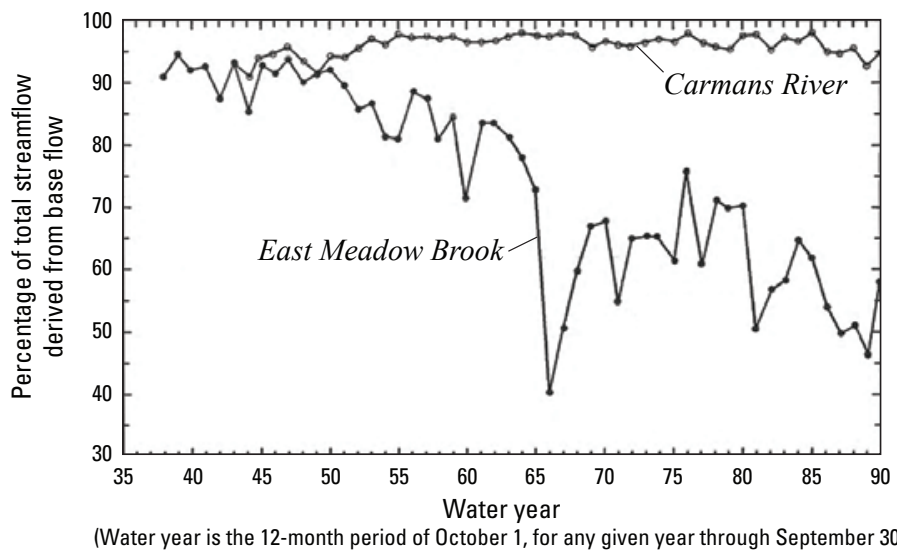
of the following year. The water year is designated by the calendar year in which it ends.)

Percentage of streamflow derived from base flow at two streams in Long Island, New York; East Meadow Brook at Freeport, N.Y., and Carmans River at Yaphank, N.Y. Decreased streamflow in East Meadow Brook, N.Y., is attributed to sewering in the urbanized watershed, which exacerbated the low streamflows during drought conditions in the 1960s. Streamflow at the Carmans River, which is in a rural setting that is not sewered, was sustained by base flow during the same period of record (Scorca, 1996).

\section{Examples of USGS Urban Hydrologic Studies}

http://pubs.usgs.gov/sir/2014/5058/

http://pubs.usgs.gov/fs/fs07603/

http://pubs.usgs.gov/sir/2014/5036/pdf/sir2014-5036.pdf

http://pubs.usgs.gov/of/2014/1184

http://pubs.usgs.gov/circ/1968/0554/report.pdf

http://pubs.usgs.gov/wri/1996/4187/report.pdf

\section{Partnering Opportunities}

As the Nation's largest hydrologic, geologic, and biologic science and mapping agency, the USGS provides scientific understanding about natural resource conditions, issues, and problems. The diversity of our scientific expertise enables us to carry out largescale, multi-disciplinary investigations and provide impartial scientific information to resource managers, planners, and other cooperators. The USGS Northeast Region Urban Landscape Capability Team is committed to continuing and expanding urban hydrologic studies needed to manage water resources of the United States. The USGS has a long history of collaborative science with a diversity of partners including local, state, Federal, and Tribal agencies; nonprofit organizations; academic institutions; watershed groups; and other water resources entities. Opportunities for jointly funded programs are available through the Cooperative Water Program (http://water.usgs.gov/coop/).

\section{References Cited}

Granato, G.E., 2013, Stochastic empirical loading and dilution model (SELDM) version 1.0.0: U.S. Geological Survey Techniques and Methods, book 4, chap. C3, 112 p., accessed April 12, 2016, at http://pubs.usgs.gov/tm/04/c03/.

Leopold, L.B., 1968, Hydrology for urban land planning-A guidebook of the hydrologic effects of urban land use: U.S. Geological Survey Circular 554, 18 p., accessed April 12, 2016, at http://pubs.usgs.gov/circ/1968/0554/ report.pdf.

Provost, A.M., Reilly, T.E., Harbaugh, A.W., and Pollock, D.W., 2009, U.S. Geological Survey groundwater modeling software-Making sense of a complex natural resource: U.S. Geological Survey Fact Sheet 2009-3105, 4 p., accessed April 12, 2016, at http://pubs.usgs.gov/fs/2009/3105/ pdf/2009-3105.pdf.

Scorca, M.P. and Ku, H.F.H., 1997, Urbanization and recharge in the vicinity of East Meadow Brook, Nassau County, New York, Part 3-Ground-water levels and flow conditions, 1988-93: U.S. Geological Survey WaterResources Investigations Report 96-4265, 39 p., accessed April 12, 2016, at https://pubs.er.usgs.gov/publication/wri964265.

\section{By Joseph M. Bell, Amy E. Simonson, and Irene J. Fisher}

\section{For more information about these USGS projects and about partnering opportunities, contact:}

USGS Northeast Region Urban Landscapes Capability Team

Email: GS-NE_ULCT@usgs.gov

or contact your local USGS office

https://www.usgs.gov/contact_us 